\title{
A Case Report of Tongue Edema due to Laryngeal Mask with Introducer
}

\section{Introducerli Laringeal Maske ile iliş̧kili Dilde Ödem}

\section{Hayrettin DAŞKAYA', Taner ÇiFTÇí ${ }^{2}$, Kadir IDIN ${ }^{1}$, Kürşat GÜL'1 Ufuk TOPUZ1 , Hakkı ÖLÇÜLÜ ${ }^{1}$ \\ ${ }^{1}$ Department of Anesthesiology and Reanimation, Bezmialem Vakif University School of Medicine, İstanbul, Turkey \\ ${ }^{2}$ Department of Anesthesiology and Reanimation, Trakya University School of Medicine, Edirne, Türkiye}

\section{ABSTRACT}

Airway management using a laryngeal mask is an especially preferred noninvasive technique because of its achievement of hemodynamic stability and ease of application in surgeries that have short surgery time and do not require specific positions such as the prone position. Although it is easily performed, serious complications may manifest rarely because of lack of experience and inappropriate choice of instrumentation. In this case report, clinical management and treatment options of tongue edema that developed because of the forgotten introducer in laryngeal mask application are presented.

Keywords: Laryngeal mask airway, tongue edema, introducer

\section{öz}

Laringeal maske ile havayolu yönetimi, hemodinamik olarak stabil, cerrahi operasyon süresi kısa olan ve prone pozisyonu gibi spesifik pozisyonları gerektirmeyen ameliyatlarda uygulama kolaylığı sağladığı için özellikle tercih edilen noninvaziv bir tekniktir. Kolay bir şekilde uygulanmasına rağmen, deneyim eksikliği ve uygun olmayan enstrümantasyon seçimi nedeniyle ciddi komplikasyonlar nadiren ortaya çıkabilir. Bu olgu sunumunda laringeal maske uygulamasında unutulmuş introdüser nedeniyle gelişen dil ödemi tablosunun klinik yönetimi ve tedavi seçenekleri sunulmaktadır.

Anahtar sözcükler: Laringeal maske, dilde ödem, introduser

\section{Introduction}

The laryngeal mask (LM) is a preferable method for short-duration surgeries that are planned to be performed under general anesthesia because it is easily and readily performed (1). The success rate of standard LM administration is closely associated with appropriate patient and LM-size selection and the skill and experience of the clinician. The introducer is an apparatus that facilitates the application of LM and must be extracted after the application. If not extracted, the pressure caused to the tongue, a highly vascularized organ, may result in hematoma (2). The elongation of surgery time may also increase the number of complications. In this case, we present a case of tongue edema related to the forgotten introducer apparatus in the LM technique, which has not been reported previously in the literature.

\section{Case Report}

A 53-year-old male patient weighing $80 \mathrm{~kg}$ diagnosed with benign prostatic hypertrophy with no known history of systemic diseases consulted for general anesthesia. Written informed consent was obtained from the patient. No physical or laboratory abnormalities were observed. The patient did not want local anesthesia. Therefore, general anesthesia with LM technique was planned considering the relatively short duration of the surgery.

After anesthesia induction was performed using $2 \mathrm{mg}$ midazolam, $2 \mathrm{mg}$ propofol and $1 \mu \mathrm{cg} / \mathrm{kg}$ fentanyl, LM appropriate to patient weight was selected. The laryngeal mask airway (LMA") with an "Introducer" "was inserted, and the cuff was ventilated with $25 \mathrm{~mL}$ of air (Figure 1). The surgery was initiated after the airway control had been performed. The tongue was examined after the insertion and was observed to be in position and free.

Cite this article as: Daşkaya H, Çiftçi T, İdin K, Gül K, Topuz U, ölçülü H. A Case Report of Tongue Edema due to Laryngeal Mask with Introducer. Bezmialem Science 2018; 6(4): 326-8.

Address for Correspondence/Yazışma Adresi: Hayrettin DAŞKAYA, Department of Anesthesiology and Reanimation,

Received / Geliş Tarihi : 22.04 .2016 Bezmialem Vakif University School of Medicine, Istanbul, Turkey E-mail: h.daskaya@gmail.com

Accepted / Kabul Tarihi: 14.08 .2017 
At the end of 35 min of surgery, LMA" was extracted after the patient was observed to have a spontaneous respiration effort and could open the mouth with verbal input. Subsequently, his tongue was observed to be edematous, and he had difficulty in swallowing (Figure 2). He was monitored in the postoperative care unit (POCU) with emergency airway management equipment because it was believed that he had a respiratory problem. The POCU entrance values were oxygen saturation $\left(\mathrm{SpO}_{2}\right)$, 94; peak heart rate (PHR), 85/min; and blood pressure (BP), 135/85 mmHg. Dexamethasone (8 mg)

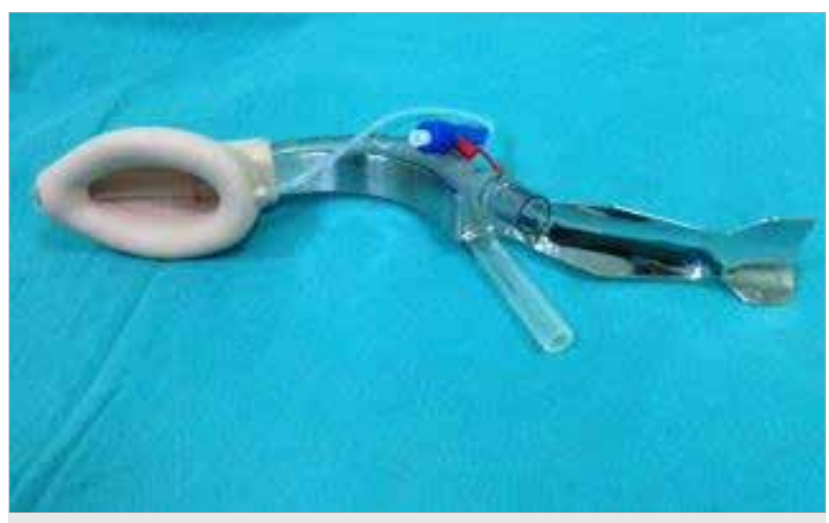

Figure 1. Flexometallic laryngeal mask airway

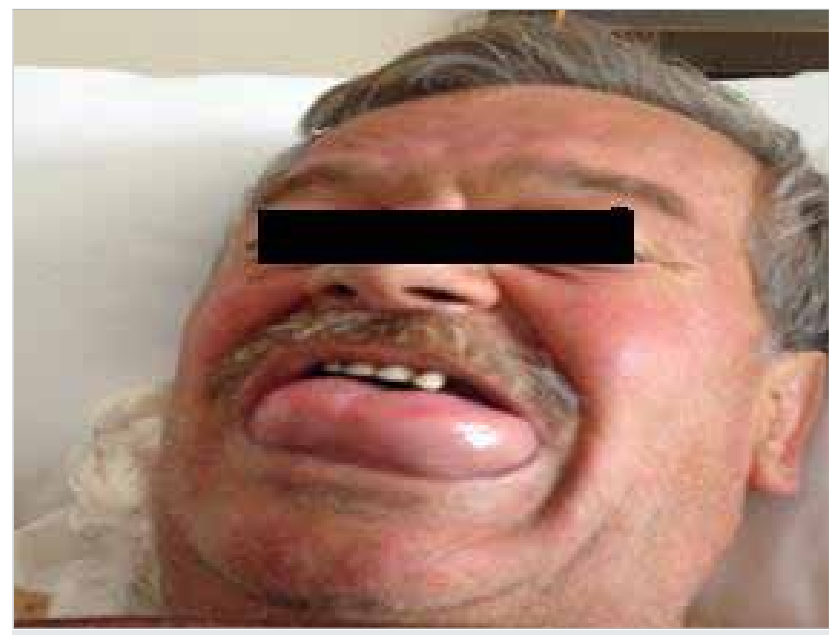

Figure 2. Photograph showing edema of the tongue

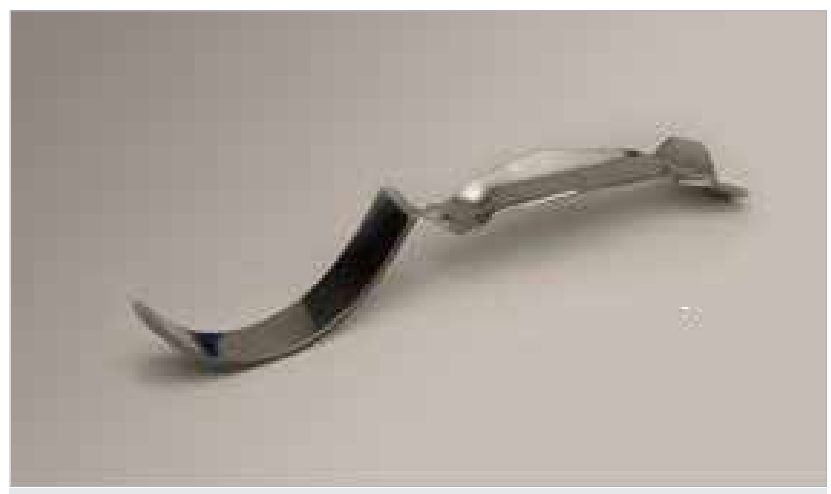

Figure 3. Introducer and atropine (1 mg) were administered and followed-up with $2 \mathrm{t} / \mathrm{min} \mathrm{O}_{2}$ given using the nasal mask in spontaneous respiration. The $\mathrm{SpO}_{2}$ level was $94 \%-97 \%$ at the patients' follow-up in POCU. Physical examination revealed no hematoma and sign of trauma, and the posterior pharynx was patent. After $1.5 \mathrm{~h}$ of follow-up, his difficulty in swallowing regressed, the $\mathrm{SpO}_{2}$ level was 96-97\%, and he was sent to the clinic. We observed that the swallowing difficulty and tongue edema was completely resolved after $24 \mathrm{~h}$ periods. There was no recurrence at the patient's $1^{\text {st }}, 2^{\text {nd }}, 3^{\text {rd }}$ and $7^{\text {th }}$ day visits.

\section{Discussion}

$\mathrm{LMA}^{\mathrm{Tm}}$ is a ring-shaped low-pressure cushion-like apparatus that is positioned at the glottis"bn where the gastrointestinal system and respiratory system converge. If fitted appropriately and its cuff is inflated, the lower end of $\mathrm{LMA}^{\mathrm{TM}}$ resides at the level of the upper esophageal sphincter with its sides pressing the piriform fossa and upper end extending to the base of the tongue. In this position, the epiglottis lies in LM facing upwards, which secures the airway open (3). In the standard $\mathrm{LMA}^{\mathrm{TM}}$ technique, low oral volume, inexperienced clinicians, and the flexible nature of the instrument reduce success rates (4). "Flexometallic Laryngeal Mask Airway" (FLMA") comprises an "Introducer" that is rigid, in proper curvature with the airway, and easily extracted from LM after the insertion, which increases the success rates (5-6). In this case, FLMA ${ }^{\text {TM }}$ was used.

Tongue edema caused by LM is a rarely-observed complication. A literature search revealed that complications occurred because of inappropriate LM-size selection and lengthened use (2). In this case, LM was appropriately selected according to patient weight and specialties. To our knowledge, there is no case reporting lingual edema caused by forgotten introducer.

External pressure applied to the tongue vessels may cause edema after surgery (7). If placed anatomically and used within tolerable time limits, the flexible nature of $\mathrm{LMA}^{\mathrm{TM}}$ does not cause a problem to tongue vascularization (8). Although FLMA $^{\prime \prime}$ is analogous to standard LMA ${ }^{\mathrm{TM}}$, it is more easily in-

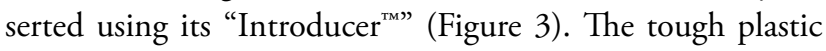
and metal combination nature of the "Introducer ${ }^{\mathrm{T} \text { ")" }}$ contributes to the pressure exerted to the base of the tongue if not extracted after the insertion of LM. In the present case, extraction of the "Introducer ${ }^{\mathrm{T} M}$ " was forgotten, and tongue edema was observed after the surgery after the removal of the LM. In the patient presented by Stillman, the surgery lasted $5 \mathrm{~h}$, and the tongue edema was associated with long surgery time and a larger size $\mathrm{LMA}^{\mathrm{Tm}}$ (2). In our case, the surgery was completed in a short time, i.e., $35 \mathrm{~min}$, and the $\mathrm{LMA}^{\mathrm{TM}}$ size was selected based on the patient's characteristics. Because surgery time was short, appropriate size $\mathrm{LMA}^{\mathrm{TM}}$ was used, and the cuff was inflated with a relatively low volume, i.e., $25 \mathrm{~mL}$, the tongue edema in this case was attributable to the "Introducer ${ }^{\mathrm{rm}}$." Twig et al reported a surgery time of $90 \mathrm{~min}$, and size: $5 \mathrm{LMA}^{\mathrm{Tm}}$ cuff 
was inflated with $30 \mathrm{~mL}$ of air. They disclosed that the edema and cyanosis in the tongue were associated with the nitrous oxide gas used in anesthesia, leading to increased cuff pressure. We did not use nitrous oxide and the cuff pressure was within normal limits.

\section{Conclusion}

If FLMA ${ }^{\mathrm{TM}}$ is planned to be used in LM administration, the "Introducer ${ }^{\mathrm{TM}}$ " should be extracted after LM is inserted. Otherwise, a spectrum of complications ranging from tongue edema to life-threatening complications may develop. We recommend routine examination of the tongue during the follow-up.

Informed Consent: Written informed consent was obtained from the patient.

Peer-review: Externally peer-reviewed.

Author Contributions: Concept - H.D., K.İ.; Design - H.D., T.Ç.; Supervision - K.İ., K.G.; Resources - H.D., U.T., H.Ö.; Materials- H.D., T.Ç., H.Ö.; Data Collection and/or Processing - H.D., U.T., K.G.; Analysis and/or Interpretation - H.D.,K.İ., H.Ö., K.G.; Literature Search - H.D., K.G., H.Ö.; Writing Manuscript - H.D., T.Ç.; Critical Review - T.Ç., H.D., U.T.

Conflict of Interest: The authors have no conflict of interest to declare.

Financial Disclosure: The authors declared that this study has received no financial support.

Hasta Onamı: Yazılı hasta onamı bu çalı̧smaya katılan hastadan alınmıştır.
Hakem Değerlendirmesi: Dış Bağımsız.

Yazar Katkıları: Fikir - H.D., K.İ.; Tasarım - H.D., T.Ç.; Denetleme - K.I., K.G.; Kaynaklar - H.D., U.T., H.Ö.; Gereçler - H.D., T.Ç., H.Ö.; Veri Toplama ve/veya İşleme - H.D., U.T., K.G.; Analiz ve/veya Yorum - H.D.,K.İ., H.Ö., K.G.; Literatür Taraması - H.D., K.G., H.Ö.; Yazıyı Yazan - H.D., T.Ç.; Eleştirel İnceleme - T.Ç., H.D., U.T.

Çıkar Çatışması: Yazarlar çıkar çatışması bildirmemişlerdir.

Finansal Destek: Yazarlar bu çalışma için finansal destek almadığını belirtmişlerdir.

\section{References}

1. Brimacombe J. The advantages of the LMA over the tracheal tube or facemask: a meta-analysis. Can J Anaesth. 1995; 42(11): 1017-23. [CrossRef]

2. Stillman P.C. Lingual oedema associated with the prolonged use of an inappropriately largelaryngeal mask airway (LMA") in an infant. PaediatricAnaesthesia. 2003; 13: 637-39 [CrossRef]

3. Janssens M, Lamy M. Laryngeal mask. Intensive Care World. 1993; 10(2): 99-102.

4. Chakravarty A, Wadhawan S. A novel technique of flexible reinforced laryngeal mask airway insertion. AnaesthIntensiveCare. 2009; 39: 669-70.

5. Kulkarni AH, Simon BP, Jose JK. A new flexible laryngeal mask airway introducer.Indian J Anaesth. 2012; 56(1): 94-5. [CrossRef]

6. Cook TM, Ford P, Craft TM, McCormick B, Ryder SA. An evaluation of the flexiguide introducer with the flexible laryngeal mask airway. AnaesthIntensiveCare. 2003; 31: 193-5.

7. Senders CW, Eisele JH. Lingual pressure induced by mouthgags. Int J Pediatr Otorhinolaryngol. 1995; 33: 53-60. [CrossRef]

8. Twigg S, Brown JM, Williams R. Swelling and cyanosis of the tongue associated with use of a laryngeal mask airway. Anaesth Intensive Care. 2000; 28(4): 449-50. 